\title{
CONSERVATION BEYOND SCIENCE: SCIENTISTS AS STORYTELLERS
}

\section{Diogo Veríssimo ${ }^{1} \&$ Miguel P. Pais ${ }^{2}$}

${ }^{1}$ David H. Smith Conservation Fellow, Andrew Young School of Policy Studies, Georgia State University, P.O. Box 3992, Atlanta, GA 30302-3992, USA

${ }^{2}$ Centro de Oceanografia, Faculdade de Ciências, Universidade de Lisboa, Campo Grande, 1749-016 Lisboa, Portugal ${ }^{2}$ MARE - Marine and Environmental Sciences Centre, Faculdade de Ciências, Universidade de Lisboa, Campo Grande, 1749-016 Lisboa, Portugal

${ }^{1}$ verissimodiogo@gmail.com (corresponding author), 2mppais@fc.ul.pt

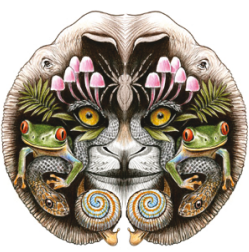

ISSN 0974-7907 (Online) ISSN 0974-7893 (Print)

OPEN ACCESS

Abstract: As scientists we are often unprepared and unwilling to communicate our passion for what we do to those outside our professional circles. Scientific literature can also be difficult or unattractive to those without a professional interest in research. Storytelling can be a successful approach to enable readers to engage with the challenges faced by scientists. In an effort to convey to the public what it means to be a field biologist, 18 Portuguese biologists came together to write a book titled "BIOgraphies: The lives of those who study life", in the original Portuguese "BIOgrafias: Vidas de quem estuda a vida". This book is a collection of 35 field stories that became career landmarks for those who lived them. We discuss the obstacles and opportunities of the publishing process and reflect on the lessons learned for future outreach efforts.

Keywords: Biologist, book, conservation, crowdfunding, education, illustration, outreach, Portugal, science communication, storytelling.

Portuguese Abstract: No nosso papel de cientistas estamos frequentemente pouco preparados e indisponíveis para comunicar a paixão pelo que fazemos com todos aqueles fora dos nossos círculos profissionais. Ao mesmo tempo, a literatura científica é habitualmente difícil ou pouco atractiva para todos aqueles sem um interesse profissional na investigação científica. Neste contexto contar uma história pode ser uma abordagem que facilita a interacção entre o leitor e os desafios profissionais que os cientistas enfrentam. Com o objectivo de mostrar ao público o que significa ser um biólogo de campo, 18 biólogos Portugueses juntaram-se para escrever o livro "BIOgrafias: Vidas de quem estuda a vida". O livro é uma compilação de 35 histórias de campo que se tornaram marcos na carreira de quem as viveu. Neste artigo discutimos os obstáculos e oportunidades do processo de publicação e reflectimos sobre como as lições aprendidas durante este processo podem ser úteis para futuros esforços de comunicação de ciência.

\section{: (I) RE $\mathbf{D}^{\circ}$ Guiding LST Conservation}

DOI: http://dx.doi.org/10.11609/JoTT.04103.6529-33

Editor: Wiebke Herding, Amsterdam, The Netherlands.

Date of publication: 26 November 2014 (online \& print)

Manuscript details: Ms \# o4103 | Received 21 July 2014 | Final received 19 September 2014 | Finally accepted 21 October 2014

Citation: Diogo Veríssimo \& Miguel P. Pais (2014). Conservation beyond science: scientists as storytellers. Journal of Threatened Taxa 6(12): 6529-6533; http:// dx.doi.org/10.11609/JoTT.04103.6529-33

Copyright: @ Veríssimo \& Pais 2014. Creative Commons Attribution 4.0 International License. JoTT allows unrestricted use of this article in any medium, reproduction and distribution by providing adequate credit to the authors and the source of publication.

Funding: This article was made possible by a David H. Smith Conservation Research Fellowship attributed to D. Veríssimo and a Fundação para a Ciência e Tecnologia (FCT) postdoctoral grant SFRH/BPD/94638/2013 attributed to M.P. Pais

Competing Interest: The authors declare no competing interests.

For Author Details and Author Contribution see end of this article.

Acknowledgements: The authors would like to thank Escola de Mar, particularly Cristina Brito for supporting the project, Gonçalo M. Rosa for the book illustrations, some of which are used to illustrate this article, José Pedro Martins for the design of the book cover, all the authors that contributed to the project and all the supporters of the crowdfunding campaign.

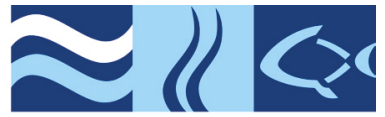

CENTRO DE OCEANOGRAFIA
Smith Fellows 
Communicating with those outside professional circles is not widely perceived to be part of a scientist's job description; for example non-academic articles do not count for advancing academic professional careers (Nadkarni 2004; Pace et al. 2010). Lack of interaction with the general public may be a major reason why the role of conservation science is not well understood, despite its key role in the management of vital natural resources upon which societies depend. For those willing to bridge the gap, one of the main challenges is finding the best approach to deliver their message (Avraamidou \& Osborne 2009). Press releases, interviews or presentations at popular scientific events often lack impact (Bjorkland \& Pringle 2001), especially when technical jargon is used excessively (Treise \& Weigold 2002). Storytelling, in contrast, has long been used to transmit knowledge in a simple but entertaining way to a variety of audiences (De Groot \& Zwaal 2007). With this in mind, we embarked on a project aimed at bringing the work and lives of field biologists to the public in a format that is free from scientific jargon and compatible with the limited time available to readers. Our goals were to communicate the passion that we, as field biologists, have for the natural world and to give the public a better idea of our day-to-day activities. Thus began the project "BIOgraphies: The lives of those who study life", in the original Portuguese "BIOgrafias: Vidas de quem estuda a vida" (Veríssimo et al. 2014).

\section{Telling the tale}

We wanted the project to provide both a channel to tackle the communication challenges described above and a mechanism to fundraise for future conservation outreach efforts. The medium chosen was a book containing a compilation of field stories written in a succinct and captivating way by biologists, conservationists and explorers. Prospective authors were given two simple rules: the maximum length of the stories was 5000 characters and they had to be presented as an engaging first-person narrative. This format was inspired by BBC Wildlife's "Tales from the Bush", a section that occupies the last page of the popular British magazine.

In order to support the written narratives with visual impact, each author was asked to provide a photograph from which an illustration (Fig. 1) was drawn (see Nash 2009; Ramanujam \& Brooks 2011). All stories were written in Portuguese because this was the mother tongue of all the authors, and because this type of content is rarely available in the Portuguese language. We wanted to focus specifically in transmitting our message to all those in Portugal, a country where careers associated with biology and field research have recently grown a strong reputation for lack of employment opportunities and professional growth (Gonçalves \& Freire 2009).

\section{Getting it down on paper}

We contacted authors mainly through word of mouth, branching from the professional network of the lead editor (D. Veríssimo). More than 100 biologists were contacted, with 18 accepting to be part of the project (Image 1). The low participation may reflect a lack of willingness to participate in outreach projects, but this self-selection probably lead to a more engaged and able group of authors, which may explain why little coaching was required and only minor edits were made to the original texts. Each author submitted between one and eight stories leading to a total of 35 . The stories had a broad geographic spread, taking place in 16 countries across all continents except Antarctica. Portugal was, unsurprisingly, the most represented country with 11 stories, followed by Uganda with four and Spain, Italy, Seychelles, Costa Rica, Madagascar and Mozambique with two stories each. Most stories took place on terrestrial environments with only eight occurring in and around the ocean. Mammals were the most popular group with 12 stories focusing on them, the same aggregate number as birds, reptiles and amphibians. Ten stories did not focus on particular biological groups, narrating memorable field work events.

Given our goal to use this publication as a fundraising tool, with all sales profits going towards future conservation efforts, we sent the finished manuscript to a total of six publishers and other institutions linked to science and biodiversity to gather editorial support to publish the book. Of the three positive responses received, the only proposal that honoured the original concept of this project was put forward by School of Sea ("Escola de Mar" in Portuguese; www.escolademar.pt), a small private company with a focus on research and outreach around biodiversity, which had published a variety of books related to the environment.

The funds required to print the first edition of the book, consisting of 500 copies with a cost of $€ 3000$, were gathered though a crowdfunding campaign managed by the editors in cooperation with the publisher. We ran the campaign on the Portuguese online crowdfunding platform PPL (www.ppl.com.pt) from the $1^{\text {st }}$ October to the $11^{\text {th }}$ November 2013 . To gather supporters, we disseminated information about the campaign through social media platforms (e.g., Facebook) on a daily basis. 


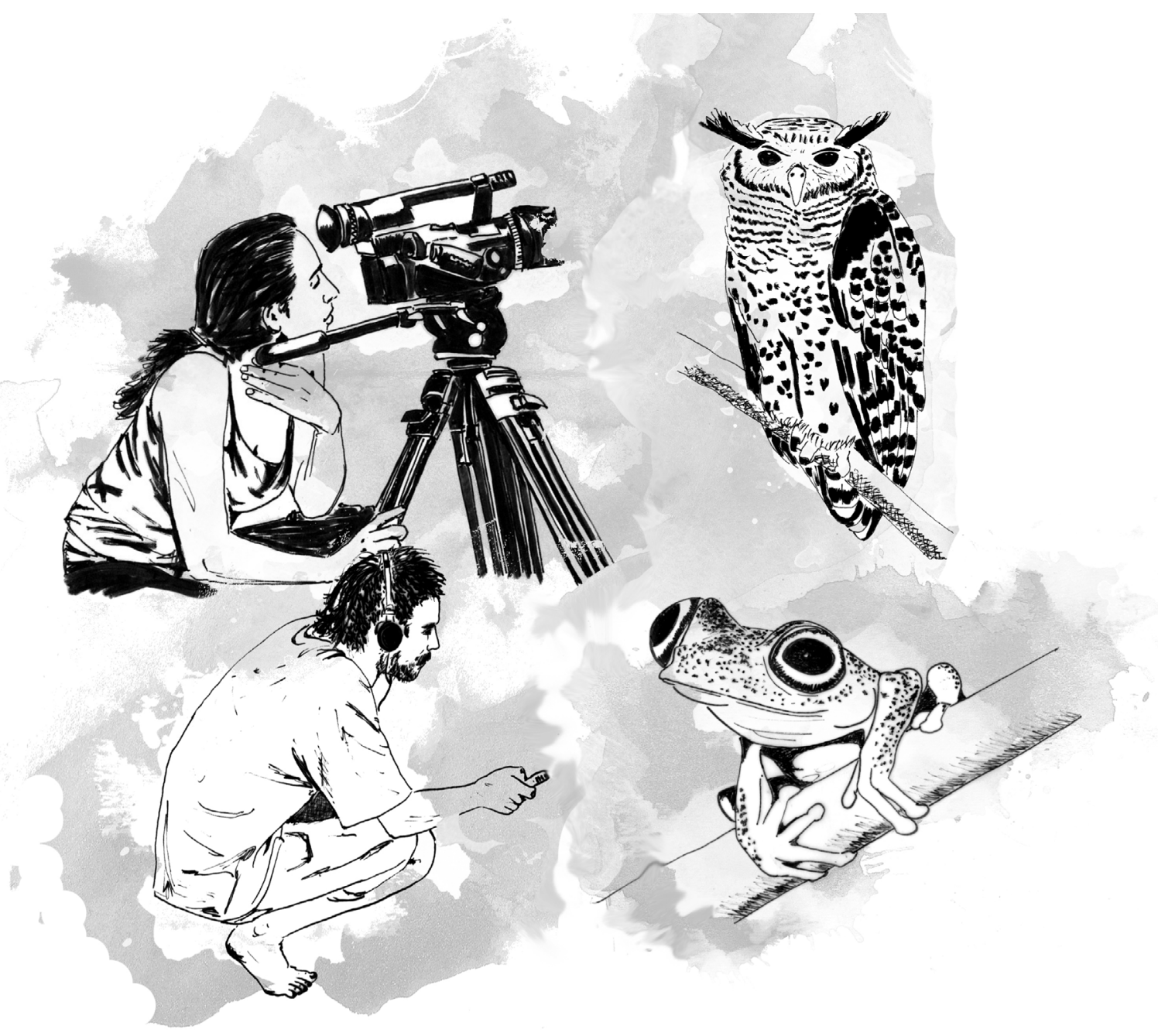

Figure 1. Illustrations of different stories of the book "BIOgraphies: The lives of those who study life", in the original Portuguese "BIOgrafias: Vidas de quem estuda a vida" @ Gonçalo M. Rosa

The support of conservation NGOs and other similar institutions was key to get the campaign out to a broader audience. We also wrote news releases for online environmental platforms such as the portal Greensavers (www.greensavers.sapo.pt) and gave interviews to several media platforms. The crowdfunding campaign was a success, receiving financial support from 162 people and raising a sum of $€ 3400$. The funding surplus was used to improve the overall design of the book, which finally went into production (Fig. 2).

Campaign supporters received the books first, in a special event followed by an official launch at the Faculty of Sciences, University of Lisbon. Several other initiatives followed these events, such as a book fair and a faculty open day, which helped raise awareness for the book and promote interaction with the authors. Ultimately, we set up sales channels for the book, including two bookshops

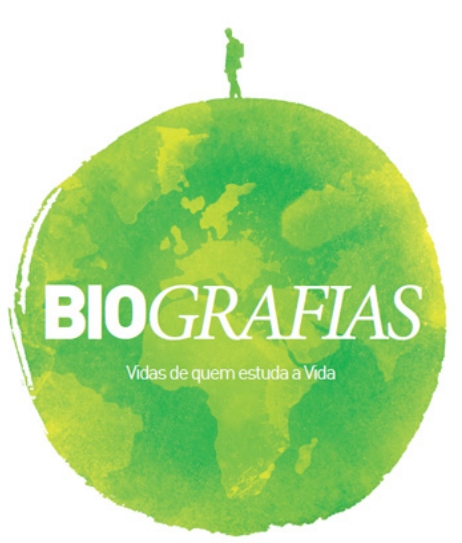

Figure 2. Cover of the book "BIOgraphies: The lives of those who study life", in the original Portuguese "BIOgrafias: Vidas de quem estuda a vida" (C) José Pedro Martins 


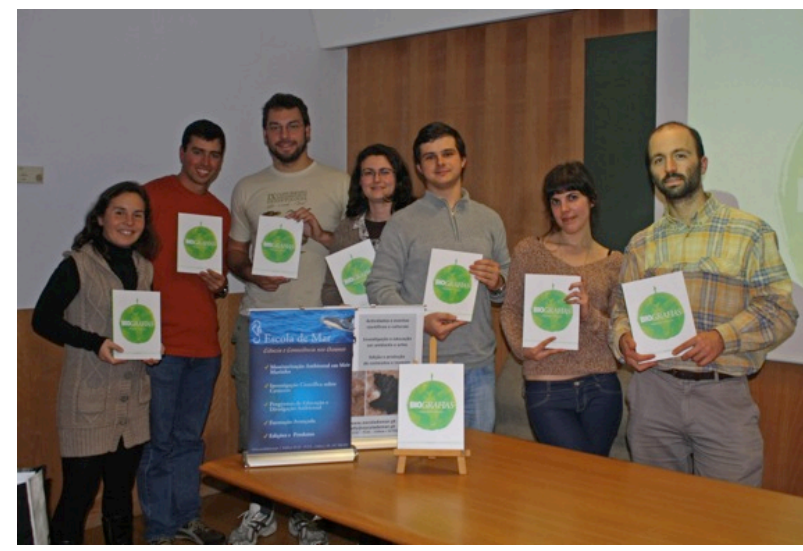

Image 1. Some of the authors of the book "BIOgraphies: The lives of those who study life", in the original Portuguese "BIOgrafias: Vidas de quem estuda a vida" at a promotional event. From left to right: Ana Luísa Nunes, Miguel Costa Leal, Marco Katzenberger, Vanessa Fonseca, Miguel Pais, Alice Estrela and Gil Penha-Lopes. The remaining authors are Diogo Veríssimo, Andreia Penado, Diana Clamote Rodrigues, Madalena Boto, Gonçalo M. Rosa, Romina Henriques, Rita Martins, Rita de Castro, Hugo Zina, João Puga and André P. Silva

in Lisbon and the online shop Naturfun (www.naturfun. pt). More than 400 books have been sold till date. The feedback received during the crowdfunding campaign, promotional events and social media has been extremely positive, a reflection of which may be the increase in the number of Facebook fans by more than $20 \%$ since the end of the crowdfunding campaign.

\section{Lessons learned}

In this project, we focused on the perspective of the protagonists instead of complex scientific results, which are often difficult to communicate. By telling our story we hope to capture the interest of the reader, who has the option to investigate further any aspect he or she finds interesting.

Developing this project was an experience from which, we learned several lessons:

(1) Scientists are often not motivated to write for general audiences, and this prevented many other authors from being part of this project. Considering how critical science communication is to the public understanding of science, it is surprising that research and education institutions do not provide more incentives and support in this arena.

(2) Transmitting science does not necessarily mean transmitting the scientific findings themselves. Many readers felt the need to voluntarily research further into the work of each scientist as they read the short stories.

(3) Field biologists and conservationists have an incredible wealth of stories to share, many of which can strike a chord with non-specialist audiences. Harnessing this potential can be a powerful tool.

(4) As with any new book, funding a first edition was a difficult step. However, opting for a crowdfunding approach turned out to be a great vehicle to raise awareness for the project, due to a nearly constant presence on social networks throughout a full month. Nevertheless, online crowdfunding requires a large investment of time and effort, together with a variety of content to be disseminated in order to create enough traction for the project.

Given the success of the initiative, we hope that this project can serve as a blueprint for other similar efforts in other countries and in other languages. One of the main communication barriers between scientists and the public is that it is often difficult to translate scientific subjects into a language that is captivating to a nonspecialist public (Treise \& Weigold 2002). By telling a story, that focuses on the human side of science, the scientist can more easily transmit the fascination that underlies his/her experience, leaving the decision to investigate further to the reader.

In a broader context it is critical to create incentives for outreach among scientists (Treise \& Weigold 2002), for example by including outreach activities in the evaluation criteria for both individual careers and research centres. Young scientists should also be given the opportunity to learn about science communication as part of their academic degrees. More than anything else, publicly funded research should be publicly disseminated to ensure wider support for governmental investment in science. This increase in outreach does not necessarily increase the workload of science professionals if there is institutional support, for example from press and media offices. And it is important not to forget tried and tested methods such as storytelling, which can play as significant a role in the future of science as they have in the history of human knowledge transmission.

\section{References}

Avraamidou, L. \& J. Osborne (2009). The Role of Narrative in Communicating Science, International Journal of Science Education 31: 1683-1707; http://dx.doi.org/10.1080/09500690802380695

Bjorkland, R. \& C.M. Pringle (2001). Educating Our Communities and Ourselves about Conservation of Aquatic Resources through Environmental Outreach. BioScience 51: 279-282; http://dx.doi. org/ 10.1641/0006-3568(2001)051[0279:EOCAOA]2.0.C

De Groot, W.T. \& N. Zwaal (2007). Storytelling as a medium for balanced dialogue on conservation in Cameroon. Environmental Conservation 34: 45-54; http://dx.doi.org/10.1017/S0376892907003682

Gonçalves, M.E. \& J. Freire (2009). Biologia e Biólogos em Portugal Ensino, Emprego e Sociedade Esfera do Caos, Setúbal, Portugal. [In Portuguese] 
Nadkarni, N.M. (2004). Not preaching to the choir: Communicating the importance of forest conservation to nontraditional audiences. Conservation Biology 18: 602-606; http://dx.doi.org/10.1111/ j.1523-1739.2004.01832.x

Nash, S.D. (2009). Some thoughts and reflections on the use of illustration in Biodiversity Education Campaigns. Journal of Threatened Taxa 1(2): 119-125; http://dx.doi.org/10.11609/jott. o1914.119-25

Pace, M.L., S.E. Hampton, K.E. Limburg, E.M. Bennett, E.M. Cook A.E. Davis, J.M. Grove, K.Y. Kaneshiro, S.L. LaDeau \& G.E. Liken (2010). Communicating with the public: opportunities and rewards for individual ecologists. Frontiers in Ecology and the Environment 8 : 292-298; http://dx.doi.org/10.1890/090168

Ramanujam, M.E. \& S.J. Brooks (2011). Wildlife art and illustration: some experiments in Auroville, India. Journal of Threatened Taxa 3: 1702-1710; http://dx.doi.org/10.11609/jott.o2673.1702-10

Treise, D. \& M.F. Weigold (2002). Advancing Science Communication: A Survey of Science Communicators. Science Communication 23: 310-322; http://dx.doi.org/10.1177/107554700202300306

Veríssimo, D., M.P. Pais \& C. Brito (eds). (2014). BIOgrafias: Vidas de quem estuda a vida. Escola de Mar. [in Portuguese], 112pp.
Author Details: DIOGO VERÍSSIMO works at the interface between social and natural sciences, having worked in Europe, Asia and Latin America in socia marketing environmental education and community based conservation. He is currently a David H. Smith Conservation Fellow, working on evaluating the impact of conservation programs that promote voluntary behaviour change. MIGUEL P. PAIS is a marine biologist who studied methodological approaches to support the use of marine fish assemblages as indicators of environmental quality during his PhD. He is currently a Postdoctoral researcher at Centro de Oceanografia/MARE focusing on individual-based modelling of marine communities.

Author Contribution: DV developed the original project concept and the contacts with the collaborating authors. DV and MPP contributed as authors and editors, with other collaborators, to the resulting book and developed partnerships with a publisher. DV and MPP wrote the article. 